\title{
Holocene alluvial sediment storage in a small river catchment in the loess area of central Belgium
}

\author{
Tom Rommens ${ }^{\mathrm{a}, *}$, Gert Verstraeten ${ }^{\mathrm{a}, \mathrm{b}}$, Pieter Bogman ${ }^{\mathrm{a}}$, Iris Peeters ${ }^{\mathrm{a}}$, Jean Poesen ${ }^{\mathrm{a}}$, \\ Gerard Govers ${ }^{\mathrm{a}}$, Anton Van Rompaey ${ }^{\mathrm{a}, \mathrm{b}}$, Andreas Lang ${ }^{\mathrm{c}}$ \\ ${ }^{\text {a }}$ Physical and Regional Geography Research Group, K.U. Leuven, Celestijnenlaan 200 E, B-3001 Heverlee, Belgium \\ ${ }^{\mathrm{b}}$ Fund for Scientific Research-Flanders, Belgium \\ c Department of Geography, University of Liverpool, Liverpool, L69 7ZT, UK
}

Received 8 July 2005; received in revised form 9 January 2006; accepted 10 January 2006

Available online 23 February 2006

\begin{abstract}
Soil erosion and sediment deposition widely affect landscape development, particularly in erosion-prone areas with loessderived soils. Nevertheless, until now, few attempts were made to quantify soil losses and sediment storage over long (centennial or millennial) timescales. In this study, the Holocene alluvial sediment storage in a small river catchment $\left(52 \mathrm{~km}^{2}\right)$ of the Belgian loess belt is estimated, and a preliminary sediment budget for the catchment is presented.

In the valley of the Nethen River (c. $13 \mathrm{~km}$ long), a detailed survey of the alluvial sediment archive was conducted. Hand augerings and percussion drillings were made along cross-valley transects at 12 locations in the catchment. AMS ${ }^{14} \mathrm{C}$ dating of peat samples provided a temporal framework for the interpretation of the cores.

Results show that the thickness of Holocene sediment deposits in the Nethen valley is 4 to $6 \mathrm{~m}$, which corresponds to a total clastic sediment mass of $\sim 14 \times 10^{6} \mathrm{t}$ stored in the valley bottom. Three alluvial units could be distinguished and associated with deposition phases from 9600 to 2900 B.C., 2900 B.C. to A.D. 1000 and A.D. 1000 to present. In contrast to the older sediments (units 1 and 2), deposits from the last 1000 year (unit 3 ) contain little organic matter. They are seldom intercalated with peat layers, and devoid of tufa. Unit 3 reaches a thickness of c. $2 \mathrm{~m}$, thereby representing $50 \%$ of the Holocene sediment mass stored in the alluvial plain. The mean sedimentation rate in the alluvial plain for this last phase is $\sim 26 \mathrm{tha}^{-1} \mathrm{a}^{-1}$, which is about tenfold larger than the sedimentation rates calculated for the older Holocene sediment units. Sediment supply towards the alluvial plain has therefore increased tremendously since Medieval times.

These results are in contrast to dating results obtained for colluvial sediments in a nearby dry valley within the catchment of the Nethen, where soil erosion and sediment deposition started in the early Iron Age and was already substantial during the Roman Age. This means that there is a time lag of about one millennium between the onset of high sedimentation rates in the upstream area and high deposition rates in the alluvial plain. This is probably caused by a change in coupling (sediment connectivity) between the plateau, slopes, and rivers. As soil erosion proceeds, first the dry zero-order valleys in the catchment act as sediment traps, and only after these are filled sediment reaches the floodplains. The preliminary sediment budget for the Nethen catchment illustrates that $50 \%$ of the sediment that was eroded during the Holocene was stored in colluvial deposits, which are mainly located on footslopes and in dry valley bottoms. Another $29 \%$ of the sediment mass is stored in the alluvial plain.
\end{abstract}

(C) 2006 Elsevier B.V. All rights reserved.

Keywords: Holocene; Alluvial sediment storage; Sediment budget; Soil erosion; Human impact; Belgium

\footnotetext{
* Corresponding author. Tel.: +32 16 326406; fax: +32 16326400 .
}

E-mail address: Tom.Rommens@geo.kuleuven.be (T. Rommens). 


\section{Introduction}

Soil erosion and sediment deposition are the main landscape-shaping processes in loess areas during the Holocene period. They result in the infilling of valleys and depressions and in the overall reduction of slope gradients, thus smoothing the topography. Insight into the intensities and rates of these processes is necessary to understand the past and present-day relations between climate, humans, and the environment. This is important if we aim at sustainable land and water management.

Direct monitoring of sediment yields at a wide range of spatial scales has resulted in a better understanding of present-day sediment dynamics. High resolution data sets have been used to establish sediment budgets, describing the input, transport, storage and export of sediment from fluvial systems (e.g., Reid and Dunne, 2003). They provide information on the relative importance of different sediment sources and sinks in the sediment pathways over short (days or years) (e.g., Page et al., 1994; Walling et al., 2002) and longer (decades) time spans (e.g., Trimble, 1999; Fryirs and Brierly, 2001), thereby showing the impact of environmental changes on sediment redistribution in river basins. Moreover, available data sets made it possible to develop and validate soil erosion models (e.g., Flanagan and Nearing, 1995; De Roo et al., 1995; Morgan et al., 1998; Van Oost et al., 2000). In contrast, over long (centennial or millennial) timescales, estimation of eroded and deposited sediment volumes is difficult. Most studies of long-term sediment dynamics focus on the analysis of different types of sediment records, such as lake sediments (e.g., Zolitschka, 1998), alluvial sediments (e.g., Macklin et al., 1991; Lang and Nolte, 1999; Taylor et al., 2000; Grossman, 2001; Larue, 2002; Kukulak, 2003; Daniels and Knox, 2005), or colluvial deposits (e.g., Lang and Hönscheidt, 1999; Foster et al., 2000; Lang, 2003; Bertran, 2004). From these archives, periods with higher and lower sedimentation rates can be identified and linked to climate and land use changes. However, the spatial resolution of the data is usually too low to derive spatially resolved quantitative information on soil erosion and sediment transport.

Attempts to establish sediment budgets for longer time periods (e.g., the Holocene), by quantifying erosion and storage, and comparing slope and river dynamics are scarce (e.g., Meade, 1982; Macaire et al., 2001; Macaire et al., 2002). Nevertheless, studies like these, which characterize the entire system of sediment sources and sinks, are essential if we want to evaluate and model the impact of land use or climate change on soil erosion and sediment transfer through river basins.

The objectives of this study are to estimate the sediment volume stored in the Holocene alluvium of a representative small river in the Belgian loess belt and to establish a chronology of sediment deposition. Furthermore, estimates of Holocene soil erosion intensities and colluvial sediment storage from previous work (Rommens et al., 2005) in this catchment are supplemented with the new data to establish a preliminary sediment budget for this river catchment.

\section{Materials and methods}

\subsection{Study area}

The Nethen is a small tributary of the Dijle River, in central Belgium (Fig. 1). It has a length of $13 \mathrm{~km}$, and a catchment area of $52 \mathrm{~km}^{2}$. Soils in the area developed on silt loam and sand. The silt loam originates from LatePleistocene loess deposits (e.g., Tavernier, 1948; Gullentops, 1954; Van Vliet and Langohr, 1981). These are underlain by Tertiary marine deposits, which are mainly sandy, except for the lowest parts of the Nethen basin where in places Tertiary clays outcrop. The dominant soil type in the region is the Luvisol (FAO, 1998).

The topography in the Nethen catchment can be characterised as gently rolling hills alternating with flat plateaus. The majority of the slopes in the catchment are less than $5 \%$ inclined, but slope gradients up to $50 \%$ occur along the major axis of the Nethen valley. The slopes oriented to the south are usually steeper, making the Nethen valley asymmetric. This is a remnant of the Pleistocene as the NNE-oriented slopes received a thicker loess cover (Goossens, 1987).

The width of the alluvial plain does not exceed $500 \mathrm{~m}$. Floodplains are generally poorly drained and used for pasture or forestry (poplar wood: Populus sp.), whereas the loamy soils in the rest of the catchment are intensively used as arable land.

Population in the catchment is concentrated in some villages along the River Nethen. Large parts of the Nethen river channel remained more or less unregulated, whereas in places watermills and fishponds were introduced from Medieval times (500-1500 A.D.) onward. Most of these constructions have disappeared by now, but they are clearly indicated on old maps; and some traces can still be recognized in the landscape morphology. Research locations were chosen away from these sites to minimize the bias caused by local anthropogenic disturbances. 

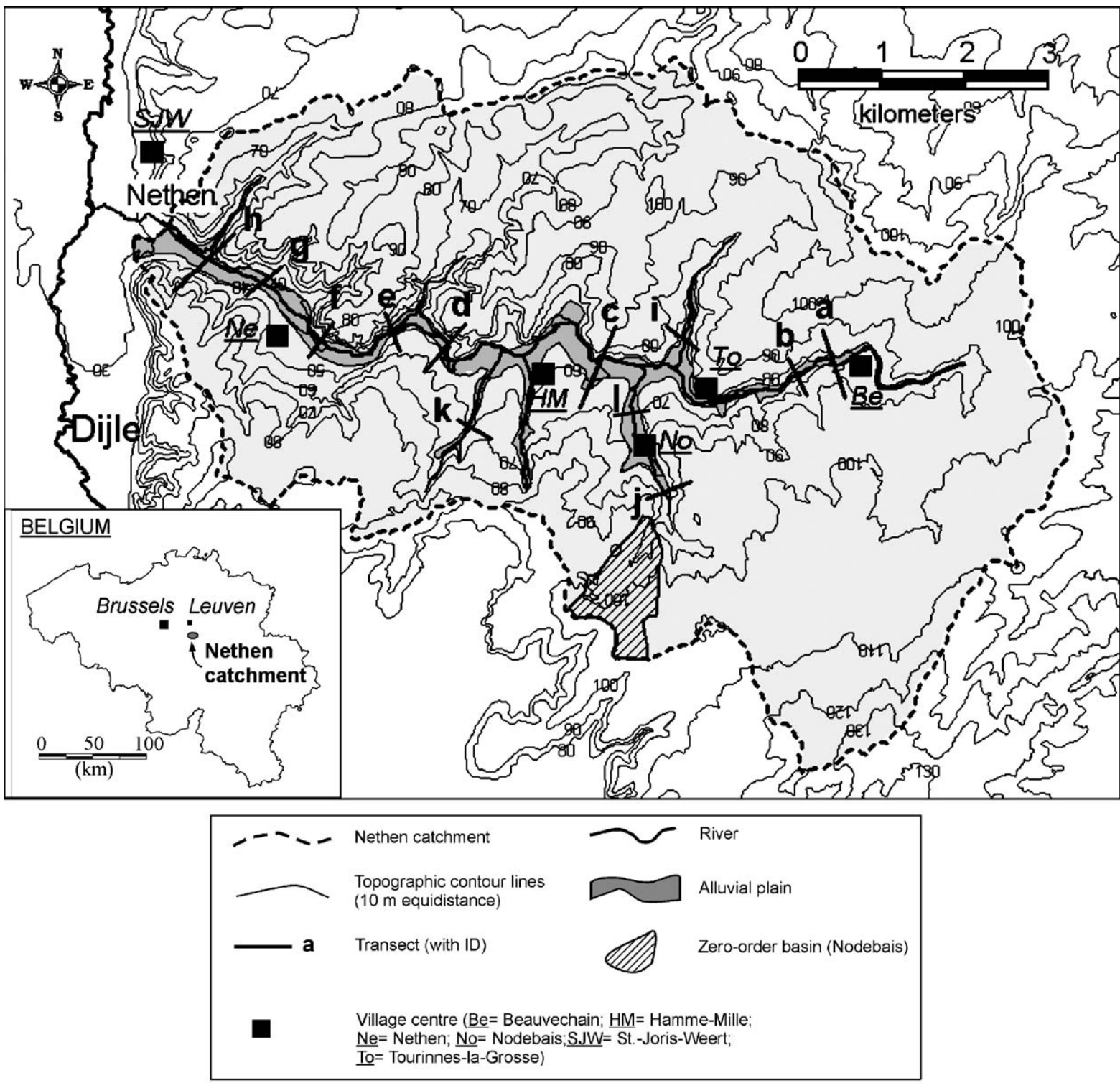

Fig. 1. Topographic map of the Nethen catchment and studied cross-sections in the Nethen-alluvium.

Central Belgium has a temperate oceanic climate with a mean annual rainfall which varies between 700 and $800 \mathrm{~mm}$ and is well distributed throughout the year.

\subsection{Methods}

Soil and sediment successions were studied in cross-valley augering transects at eight locations along the Nethen and in three large tributaries. An Edelman hand auger was used to recover sediment and to establish the stratigraphy and texture of sediment deposits. Presence of $\mathrm{CaCO}_{3}$ in the soils and sediments was tested with $\mathrm{HCl}(1 \mathrm{M})$. Samples for texture analysis and AMS ${ }^{14} \mathrm{C}$ dating were taken from cores retrieved with a percussion drill. In total, 106 auger cores and 9 percussion drills were retrieved. Laboratory texture analysis was done with the sievepipette method. Carbonates were determined by digestion with $\mathrm{HCl}$, and organic matter was determined by $\mathrm{H}_{2} \mathrm{O}_{2}$ oxidizing.

For calculating sediment volumes, the alluvial plain was divided into twelve homogenous zones, and each of them represented by a central transect. Based on the augering results stratigraphical cross sections were drawn for each transect. In each cross section, three 
different alluvial units could be distinguished (see below). The volume of each unit was calculated as (Fig. 2):

$V_{\text {alluv.unit }}=A_{\text {alluv.unit }} \times d($ mean $)=A_{\text {alluv.unit }} \times(\mathrm{CS} / W)$

where:

CS is the cross-sectional area of a unit in a specific transect $\left(\mathrm{m}^{2}\right)$;

$V_{\text {alluv.unit }}$ is the volume of sediment $\left(\mathrm{m}^{3}\right)$ of a unit represented by cross section CS;

$A_{\text {alluv.unit }}$ is the area $\left(\mathrm{m}^{2}\right)$ of the alluvial zone represented by cross section CS;

$d$ (mean) is the mean depth of sediments along the cross section; and

$W \quad$ is the width (m) of the alluvial plain at the central transect.

For uniform sediment bodies, the sediment mass in an alluvial unit $\left(M_{\text {alluv.unit }}, t\right)$ can be calculated as

$$
\begin{aligned}
M_{\text {alluv.unit }} & =V_{\text {alluv.unit }} \times \mathrm{DBD} \\
& =A_{\text {alluv.unit }} \times(\mathrm{CS} / W) \times \mathrm{DBD}
\end{aligned}
$$

where DBD is the dry bulk density of the sediment $\left(\mathrm{t} / \mathrm{m}^{3}\right)$.
In the alluvial fill of the Nethen, peat and organic rich sediments intercalate with minerogenic sediments. For these mixed sediment bodies a different approach was used. The mass of clastic sediment in each stratum can be calculated by taking into account the percentage of organic matter $(\% \mathrm{OM})$, the dry bulk density of the organic matter $\left(\mathrm{DBD}_{\mathrm{OM}}\right)$ and the dry bulk density of the clastic component $\left(\mathrm{DBD}_{\mathrm{ms}}\right)$ (e.g., Verstraeten and Poesen, 2001a):

$$
M_{\text {alluv.unit }}=V_{\text {alluv.unit }} \times \frac{1}{\left(\frac{\% \mathrm{OM} / 100}{\mathrm{DBD}_{\mathrm{om}}}\right)+\left(\frac{1-(\% \mathrm{OM} / 100)}{\mathrm{DBD}_{\mathrm{ms}}}\right)} .
$$

The calculation of minerogenic sediment masses thus requires several parameters to be estimated, each of which can only be quantified with a certain precision. The overall errors of sediment volumes and masses can be estimated using Gaussian error propagation if all variables are independent, and values are normally distributed.

For $u=f\left(x_{1}, x_{2}, \ldots x_{j}\right)$ and all $x_{j} \mathrm{~s}$ are independent, $\mathrm{Su}$, the standard deviation of $u$, is given by

$\mathrm{Su}=\sqrt{\sum_{i=1}^{j}\left(\partial u / \partial x_{i}\right)^{2} \cdot\left(\mathrm{Sx}_{i}\right)^{2}}$
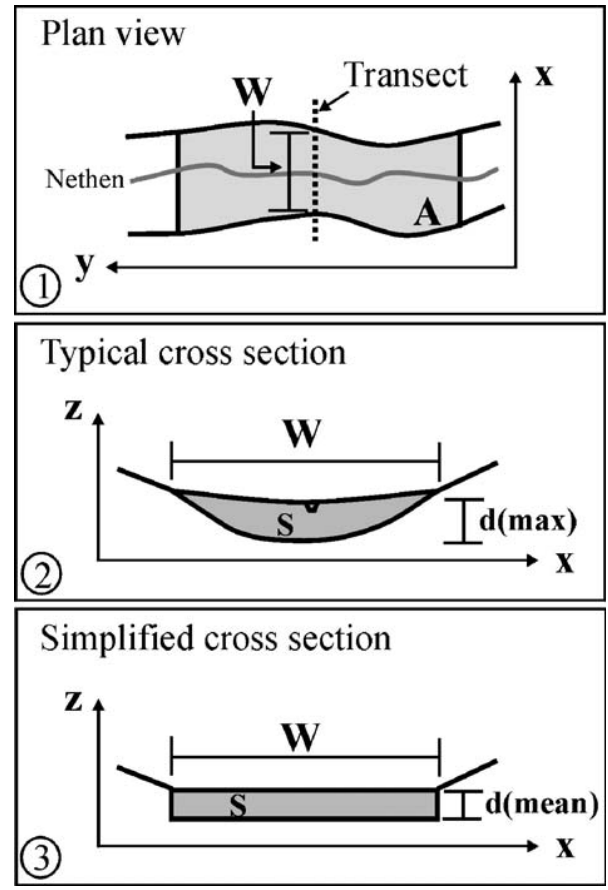

Fig. 2. Calculation of alluvial sediment volume. $W$ : width of alluvial plane at the location of a transect; $A$ : area of the alluvial zone; $S$ : area of the sediment fill estimated in the cross section; $d(\max )$ : maximum depth of Holocene alluvium; $d($ mean $)=S / W$. 
where $\mathrm{Sx}_{i}$ is the standard deviation of $x$; and $\Delta u$, the standard error of $u$, is given by:

$\Delta u=\sqrt{\sum_{i=1}^{j}\left(\partial u / \partial x_{i}\right)^{2} \cdot\left(\Delta x_{i}\right)^{2}}$

where $\Delta x_{\mathrm{i}}$ is the standard error of $x_{\mathrm{i}}$ (Parrat, 1961).

Relative errors can be calculated by:

$\operatorname{RE}(u)=\frac{\sqrt{\sum_{i=1}^{j}\left(\partial u / \partial x_{i}\right)^{2} \cdot\left(\operatorname{RE}\left(x_{i}\right) \cdot x_{i}\right)^{2}}}{u}$

with $\operatorname{RE}\left(x_{i}\right)$ the relative error on $x_{i}$.

Errors on the measurement of the coring depth (d; Fig. 2), dry sediment bulk density and alluvial plain area $\left(A_{\text {alluv.unit }}\right)$ on the digital soil map are independent and normally distributed. At several locations, parallel cores with hand augers and percussion corers were taken. From these, a relative error of $5 \%$ on the observed depths was estimated. A value of $1.42 \pm 0.13 \mathrm{t} / \mathrm{m}^{3}$ was used for $\mathrm{DBD}_{\text {min.sed. }}$ of the alluvium. This is the average value and the standard deviation of 16 samples. $\mathrm{DBD}_{\mathrm{O} . \mathrm{M}}$. was taken from the literature as $0.35 \pm 0.15 \mathrm{t} / \mathrm{m}^{3}$ (e.g., Brady, 1990; Locher and de Bakker, 1994; Verstraeten and Poesen, 2001b). Digitalization of the alluvial polygons, with an accuracy of $2 \mathrm{~mm}$, on the $1: 10,000$ soil map causes an error on the area of less than $10 \%$.

Imprecision introduced by the methodology for discriminating the sediment units are difficult to account for. The delineation of these units was not always straightforward and, after all, based on a relatively limited amount of augering interpretations. Conditions for Gaussian error propagation may not be valid here. The uncertainty on the limits between sediment units was therefore estimated at $\pm 0.25 \mathrm{~m}$, and this error margin was introduced into the volume calculations. The position of the border of the alluvial deposits on the soil map (Baeyens et al., 1957; Baeyens, 1958; Baeyens and Dudal, 1959) was evaluated during the field work and proved to be fairly accurate. Imprecision on the soil map was further not taken into account. Laboratory analyses of 48 samples showed typical contents of organic matter $(\% \mathrm{OM})$ in the order of $0.5 \%$ for sediments that were classified as "poor in organic matter", $2.5 \%$ for

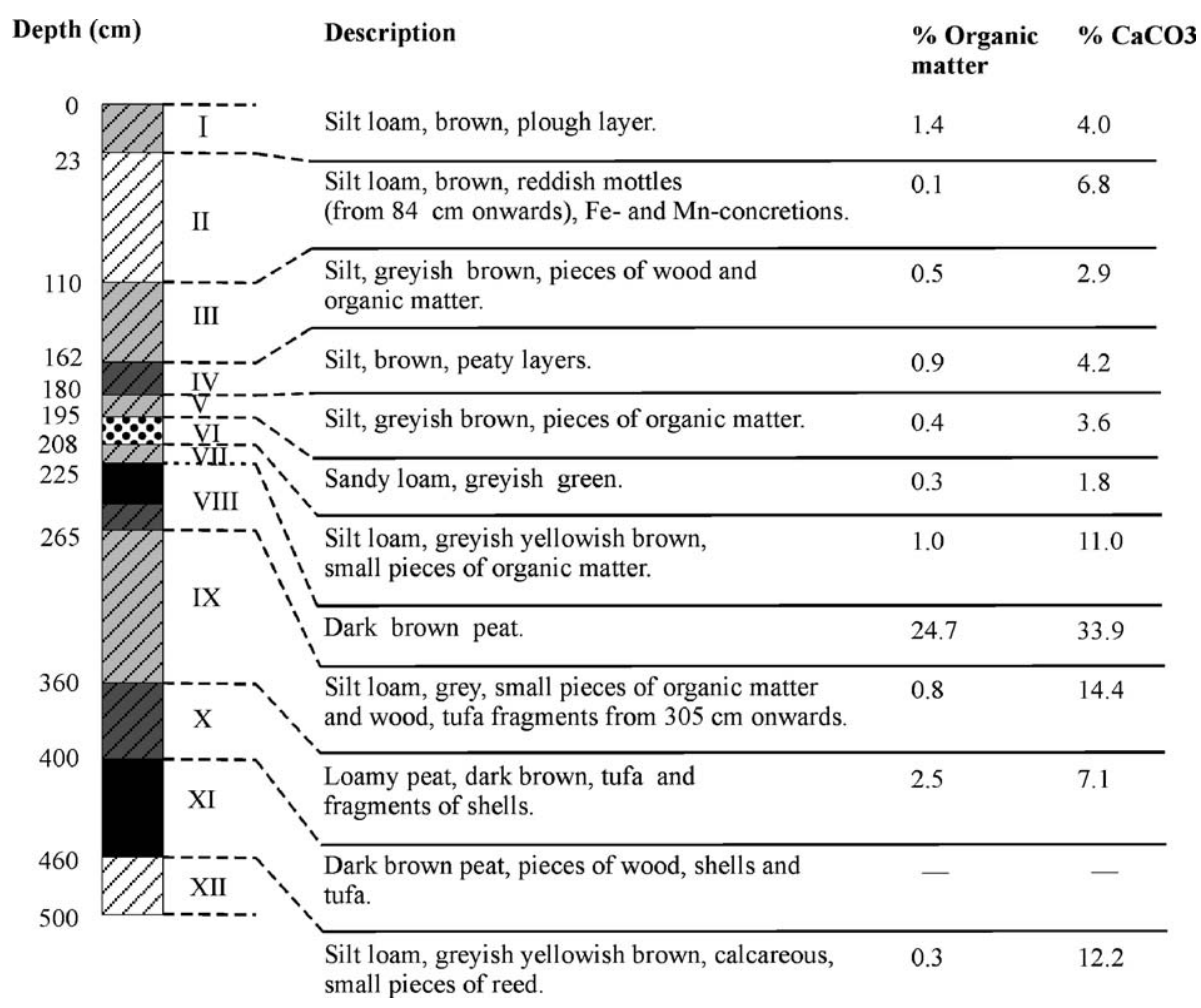

Fig. 3. Sediment profile from drilling core extracted in transect d (see Fig. 4, core at c. $90 \mathrm{~m}$ ). Sediment texture according to the USDA classification (Soil Survey Staff, 2003). 
sediments "rich in organic matter", and $20 \%$ for "peaty" sediments. These values were considered constant in the error calculation, because organic matter content and bulk density are correlated. Sensitivity of the results to varying values of $\% \mathrm{OM}$ was tested by repeating the calculations using minimal and maximal values of the dataset. This yielded results which only differed $3 \%$ to $15 \%$.

\section{Results}

\subsection{Characteristics of the Nethen sediments}

The valley of the River Nethen is filled with Holocene sediments that reach a depth of 4 to $6 \mathrm{~m}$ in the axis of the valley. Pre-Holocene sediments were not recovered or recognized in every augering. However, in most of the transects early Holocene peaty strata, Late-Pleistocene calcareous loess, or even Tertiary sands or clays were observed in some of the cores; so it was possible to approximate the depth of Holocene sediments.

The sediment profile in a typical drilling core can be seen in Fig. 3. In Figs. 4 and 5, a cross section and the longitudinal section along the Nethen River are shown, respectively. The majority of the Holocene sediments consist of silt loam, loam, and sandy loam deposits (Soil Survey Staff, 2003). Sands are rarely found. Although Tertiary sand crops out at several places in the study area (especially on the steepest slopes), its contribution to the texture of the alluvial fill of the Nethen valley is rather limited.

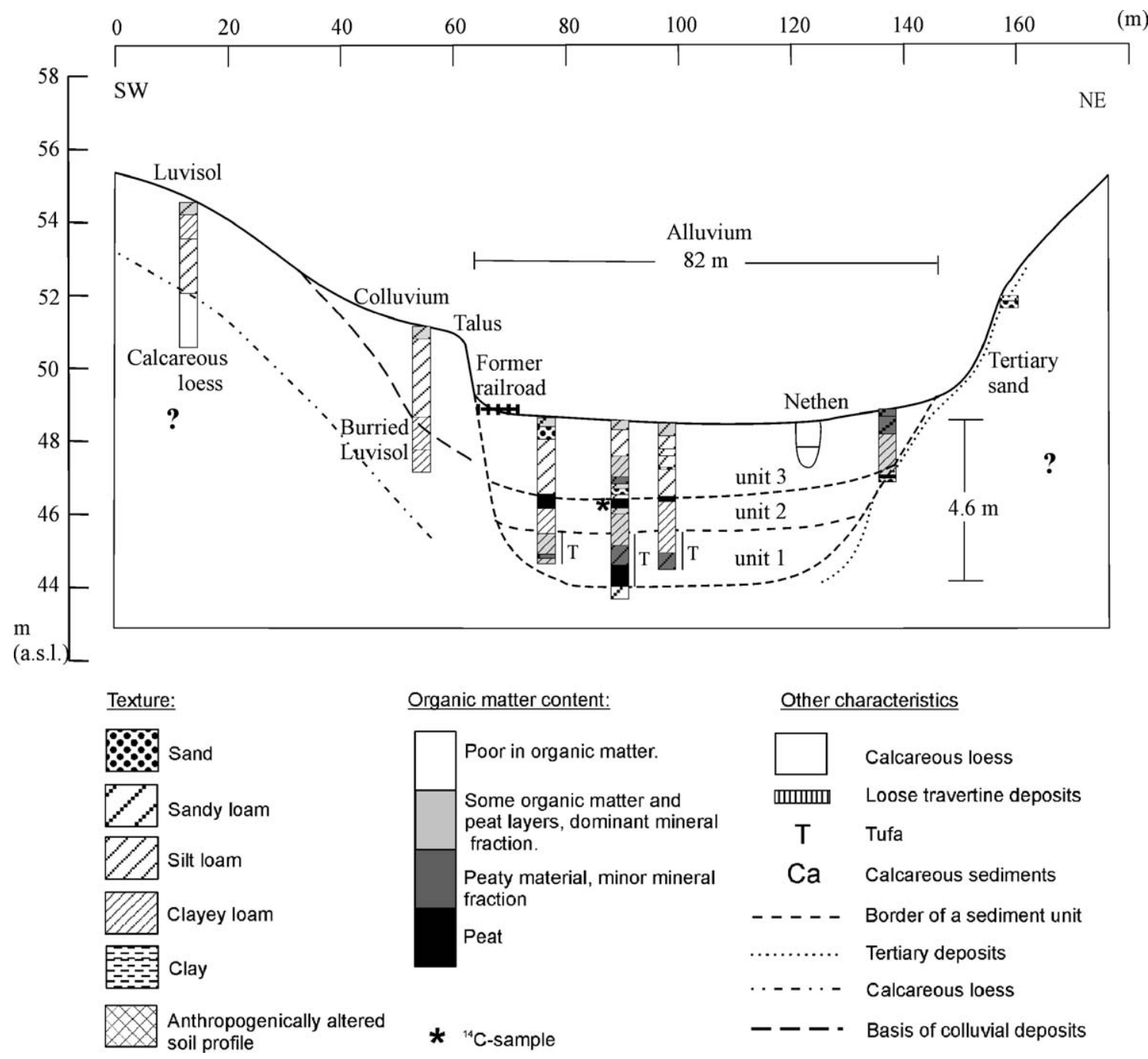

Fig. 4. Cross section d through the valley bottom of the Nethen River (see Fig. 1 for location). 


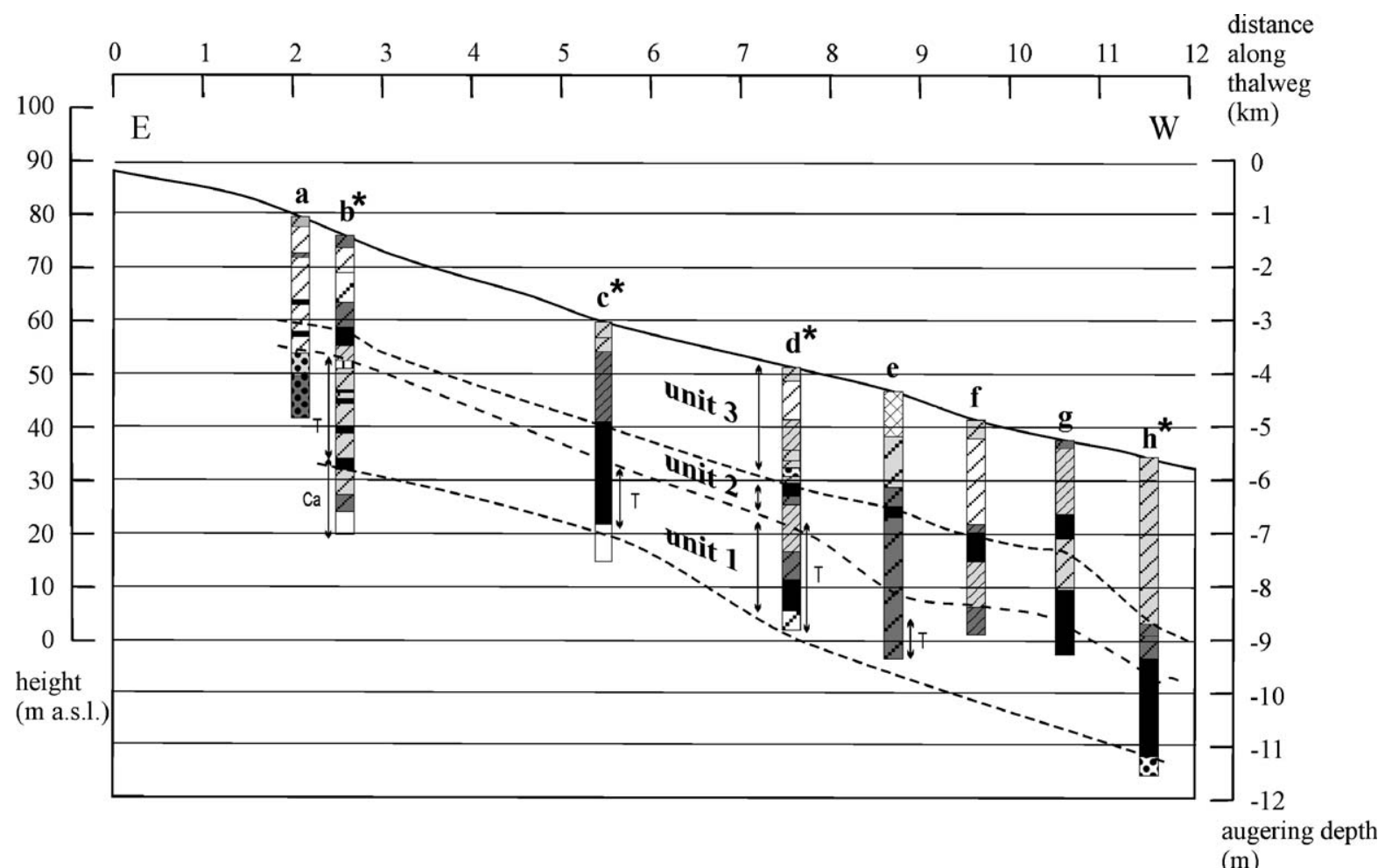

Fig. 5. Longitudinal profile of the Nethen River. Sampling locations for ${ }^{14} \mathrm{C}$-dating are indicated with an asterisk $(*)$. Note that vertical scales for topography (left) and augerings (right) are different. (Legend: see Fig. 4.)

The stratigraphy of the deposits along the Nethen shows a rather complex alternation of silty and loamy strata, peaty soils, and peat of variable thickness and at variable depths. However, two important peat strata can be distinguished when analysing the augering results. Unit 1 has its top surface at a depth of about $3.5 \mathrm{~m}$, and unit 2 is found at approximately $2 \mathrm{~m}$ depth (Fig. 6).

In several augerings, tufa deposits are found, together with other calcareous remains (shells). These calcareous strata are generally located at depths greater than $2.75 \mathrm{~m}$ (Fig. 6).

\subsection{Dating results}

Dating efforts were concentrated to determine when the phases of peat growth and organic matter accumulation stopped (Table 1). For example, peat samples were taken from a core in transect b (Fig. 1) at depths of about 2 and $3.70 \mathrm{~m}$. The calibrated radiocarbon age of peat at $3.65-3.75 \mathrm{~m}$ depth is $6380-6090$ B.C. $(2 \sigma)$. A peat stratum at $1.90 \mathrm{~m}$ depth in the same core returned a calibrated radiocarbon age of A.D. $1300-1430(2 \sigma)$. At three other locations in the Nethen valley (transects $\mathrm{c}, \mathrm{d}$ and h; see Fig. 1), the ages of peat strata overlain by mineral sediments were determined. The calibrated radiocarbon age of peat from $2.30 \mathrm{~m}$ depth is A.D. 640 $810(2 \sigma)$, from $1.60 \mathrm{~m}$ depth A.D. $1020-1210(2 \sigma)$ and from the deepest peats at 3.20 and $5.50 \mathrm{~m} \mathrm{4260-3990} \mathrm{B.}$ C. $(2 \sigma)$ and $4230-3970$ B.C. $(2 \sigma)$, respectively. In one of the tributaries of the Nethen (transect 1), organic matter at 1.60 and $2.05 \mathrm{~m}$ depth returned an age of A.D. 1300-1420.

Two previously published radiocarbon dates (Mullenders et al., 1966) were used as well. The samples were taken from peat layers at 5.10 and $4.10 \mathrm{~m}$ depth and date from 5650-4950 B.C. to 3350-2450 B.C., respectively.

\subsection{Holocene sediment volumes and masses in the Nethen alluvial fill}

Holocene sediment deposits were divided into three strata (Fig. 6). Unit 1 mainly exists of peat and tufa, below 3 to $3.5 \mathrm{~m}$ depth. On top of that lays unit 2, which generally ends in a peat at a depth of $\sim 2 \mathrm{~m}$. There begins the uppermost and youngest loamy stratum (unit 3). 


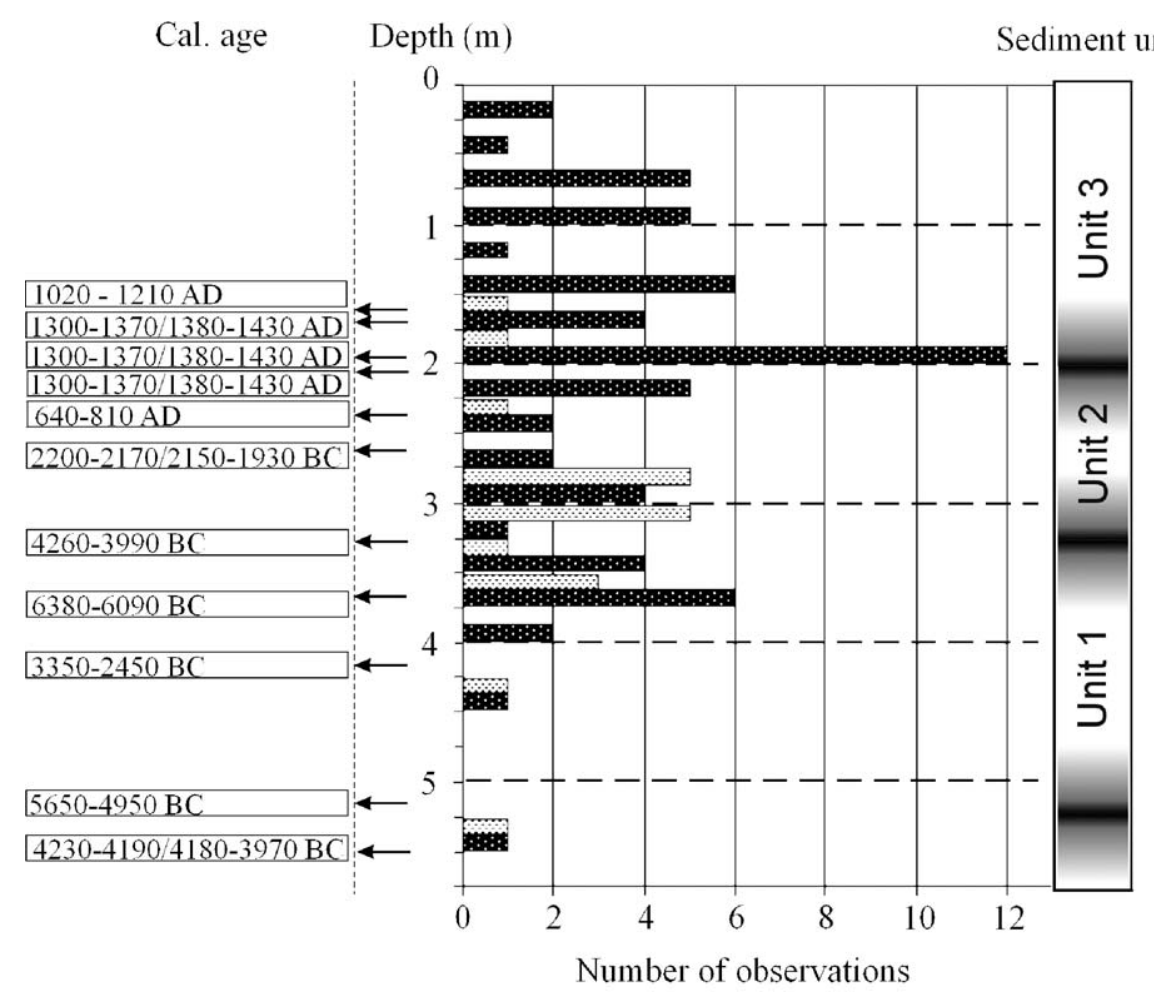

\section{Depth to tufa $(\mathrm{n}=19)$. \\ \$3 Depth to peat strata $(n=64)$.}

Fig. 6. Frequency analyses of the depth to peat strata and the minimum depth to tufa in cores from the alluvium. Calibrated age $(2 \sigma)$ and depth of available samples from different locations in the alluvium are shown.

Sediment volumes and masses were calculated for these three alluvial units using Eqs. (1) and (3) (Table 2). A total volume of Holocene sediment in the order of $(10.92 \pm 1.94) \times 10^{6} \mathrm{~m}^{3}$ is stored along the Nethen and its tributaries. This corresponds to a total clastic sediment mass of $(13.77 \pm 6.11) \times 10^{6} \mathrm{t}$. About half of this volume is stored in unit 3, the youngest stratum.

Based on the radiocarbon dating results, a chronological framework for the phases of sediment deposition of units 1, 2, and 3 was established. Phase 1 probably starts at the beginning of the Holocene (9600 B.C.) and ends around 2900 B.C. (the most probable youngest date obtained on unit 1; Lv. 277; 3350-2450 B.C.) at the end of the Atlantic Period. Phase 2 starts around 2900 B.C. and ends around A.D. 1000, in Medieval times. This age is chosen because it lies in the middle of the interval [A.D. 640-A.D.1430], which contains the five radiocarbon ages obtained on peaty strata directly underlying unit 3. Consequently, 400year was assigned as uncertainty from the deviation of these dating results.

The average accumulation rate (Table 2; Fig. 7) in the alluvial plain for the entire Holocene is $0.4 \pm 0.1 \mathrm{~mm}$ $\mathrm{a}^{-1}$. Before the Middle Ages, accumulation rates were low ( $\sim 0.2$ to $\left.0.3 \mathrm{~mm} \mathrm{a}^{-1}\right)$ and mainly from peat growth, whereas during the last 1000 year it was an order of magnitude higher $\left(2.5 \pm 1.2 \mathrm{~mm} \mathrm{a}^{-1}\right)$ and mainly reflects clastic deposition.

\subsection{A sediment budget for the Nethen catchment}

In a 100 ha, zero-order basin in the southern part of the Nethen-catchment (see Fig. 1), eroded and deposited sediment volumes were calculated, based on soil truncation and colluvial deposition (Rommens et al., 2005). The small catchment was divided into morphometric units according to slope gradient $(0-3 \%, 3-5 \%$, $5-8 \%$, and $>8 \%$ ), and a fifth unit for the valley bottom, containing the footslopes $(<8 \%)$ and the concave thalweg (Fig. 8A). Average soil profile truncation as well as the average depth of the colluvium in each of the morphometric units was estimated based on a dense network of soil augerings. The small basin is seen as characteristic for most of the Nethen catchment. To obtain a tentative sediment budget for the entire 


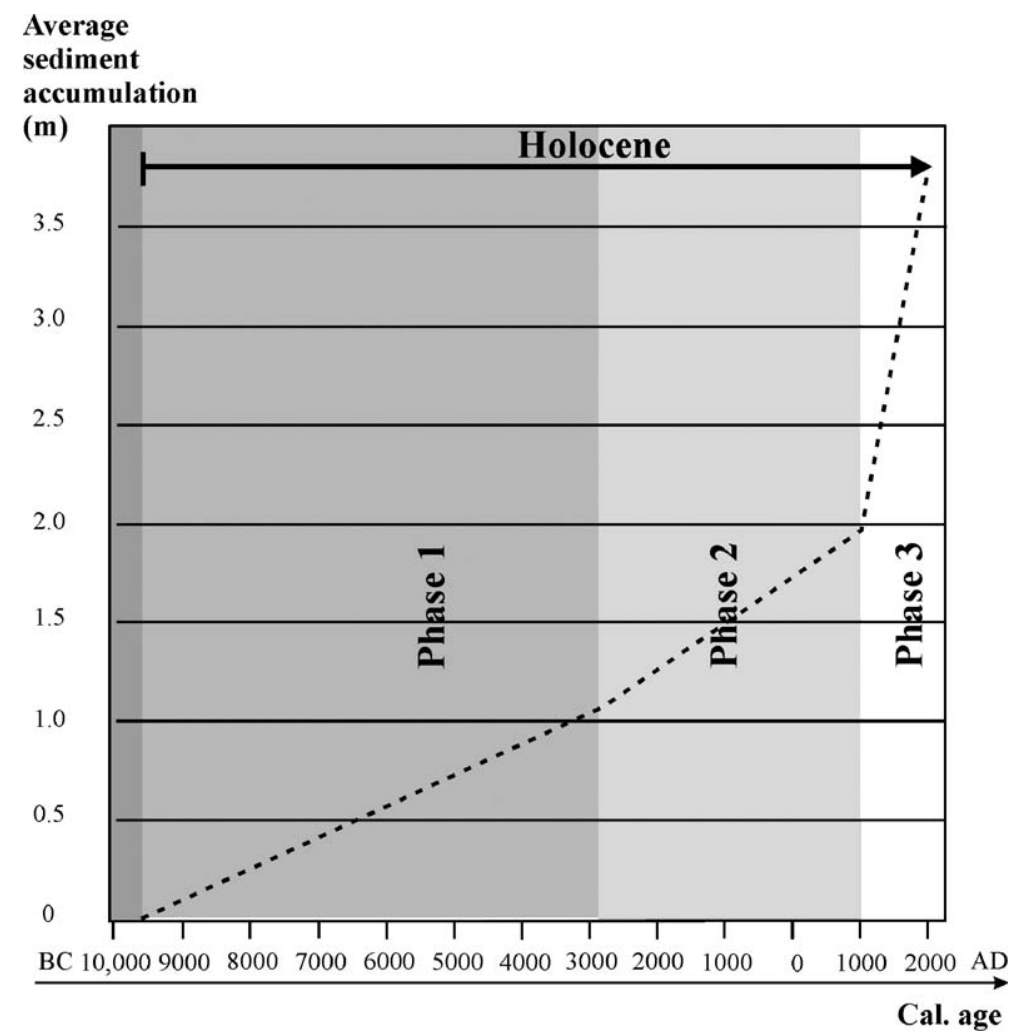

Fig. 7. Evolution of the average sediment accumulation depth in the Nethen alluvial plain during the Holocene.

catchment the same morphometric units were calculated for the Nethen catchment based on the digital elevation model of the area. Erosion and deposition were calculated as:

$E_{\text {tot }}=E_{\text {mean }} \times A_{\text {unit }} \times \mathrm{DBD}$

$D_{\text {tot }}=D_{\text {mean }} \times A_{\text {unit }} \times \mathrm{DBD}$

where $E_{\text {tot }}$ and $D_{\text {tot }}$ are total eroded and deposited sediment masses $(t)$ for a morphometric unit; $E_{\text {mean }}$ and $D_{\text {mean }}$ are mean erosion and deposition magnitude $(m)$ for a morphometric unit that were determined in a characteristic 100 ha zero-order basin (Rommens et al., 2005); $A_{\text {unit }}$ is the area of the morphometric unit $\left(\mathrm{m}^{2}\right)$; and DBD is the mean dry bulk density of the sediment $\left(\mathrm{t} / \mathrm{m}^{3}\right)$.

Here as well measurement errors of $10 \%$ and $5 \%$ were assigned to areas and depths, respectively. The dry bulk density of 32 samples (18 from soil and 14 from sediment) collected in zero-order basins in the study area was $1.51 \pm 0.10$ (average value and standard deviation). Propagation of these errors was calculated using Eq. (5). Monte Carlo simulations showed that the uncertainty on $E_{\text {mean }}$ and $D_{\text {mean }}$ due to the limited augering density is in the order of $10 \%$ to $30 \%$. Taking into account the possible difficulties in soil and sediment profile interpretation and the augering densities for each class (see: Rommens et al., 2005), an uncertainty of $10 \%$ was assigned to the mean erosion depths on the slopes and in the valleys, $30 \%$ for average erosion and deposition in the plateau class (slope gradient: $0-3 \%$ ), and $20 \%$ for other deposition heights.

Results are listed in Table 3 and depicted in Fig. 8B. Overall $(47.85 \pm 9.08) \times 10^{6} \mathrm{t}$ of sediment have been eroded in the Nethen catchment during the Holocene period. Almost $50 \%$ of this mass $\left((23.75 \pm 8.54) \times 10^{6} \mathrm{t}\right)$ is stored in colluvial deposits on the plateau and footslopes and in dry valley bottoms. Twenty-nine percent $\left((13.77 \pm 6.11) \times 10^{6} \mathrm{t}\right)$ was deposited along permanent streams of the Nethen and its tributaries. The rest of the eroded sediments $(21 \%$, or $(10.33 \pm$ $19.54) \times 10^{6} \mathrm{t}$ ) left the Nethen catchment and was delivered to the Dijle River, the higher order stream.

\section{Discussion}

\subsection{Sedimentation history of the Nethen valley}

Sediment survey and dating results from this study, together with results of previous research in the region (Mullenders et al., 1966) allows us to differentiate the 
A

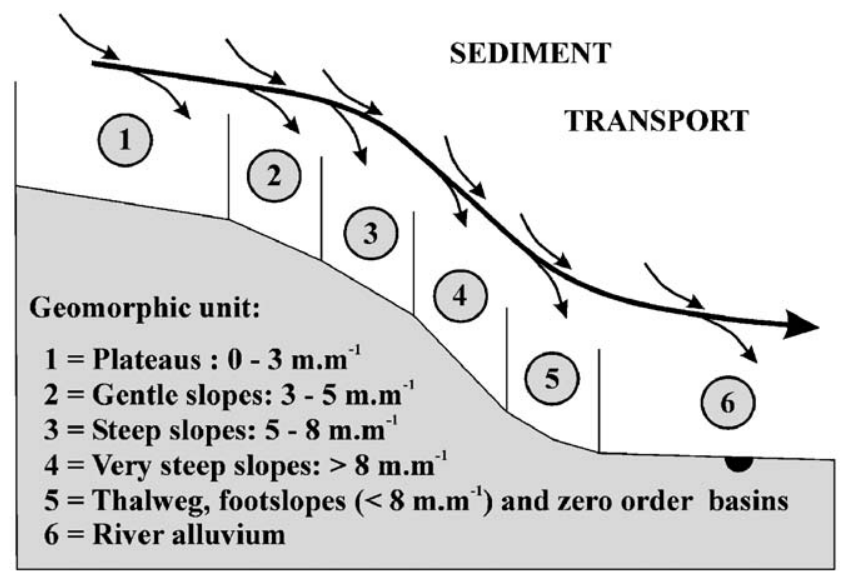

$\mathbf{B}$

SOIL

EROSION

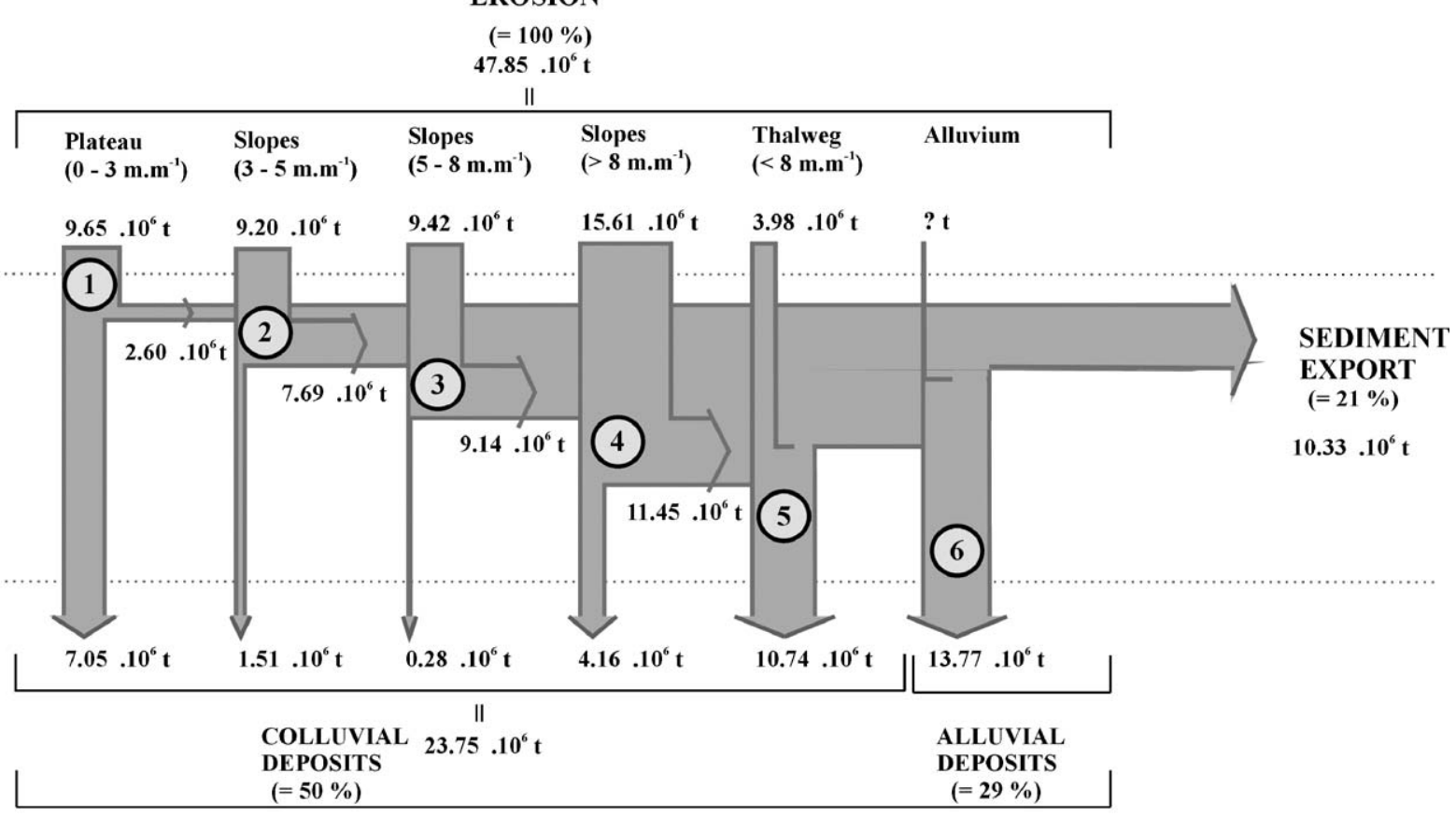

SEDIMENT

DEPOSITION

Fig. 8. (A) Schematic representation of the geomorphic units (plateaus, hillslopes, thalwegs, alluvium) in the Nethen catchment, used for calculating the sediment budget. (B) Holocene sediment distribution over these units in the Nethen catchment ("export" from each unit is calculated as the difference between estimated erosion and deposition).

alluvial fill of the Nethen into three sedimentation phases.

Sediment unit 1 is characterized by peat and peaty loam, intercalated with tufa and is located between $\sim 3$ and $\sim 6 \mathrm{~m}$ depth. Its accumulation ended around 2900 B.C., and thus it represents deposits from the early Holocene biozones Preboreal (starting at $\sim 9600$ B.C.), Boreal and Atlanticum. The peat stratum of the Atlanticum has already been described and dated at several locations in the alluvial plain of the Dijle River, downstream of the Nethen (e.g., Mullenders and Gullentops, 1957; De Smedt, 1973). Moreover, the study of travertine deposits and tufa in a number of small Belgian river valleys indicates that these deposits mainly formed during the Boreal and Atlanticum biozones and ceased in the second half of the Holocene (Geurts, 1976). Our data confirm these findings. 
Table 1

Radiocarbon ages for the Nethen sediments

\begin{tabular}{|c|c|c|c|c|}
\hline Depth $(\mathrm{cm})$ & Radiocarbon age (lab code) & Calibrated age $^{\mathrm{a}}$ & Location, core & Sampled material \\
\hline \multicolumn{5}{|c|}{${ }^{14} C$-dates obtained in this study } \\
\hline $190-200$ & $560 \pm 30$ BP (Beta-192001) & 1300-1370/1380-1430 A.D. & Beauvechain (Transect b) & $\begin{array}{l}\text { Peaty stratum } \\
\text { (c. } 0.40 \mathrm{~m} \text { thick) }\end{array}$ \\
\hline $365-375$ & $7380 \pm 40$ BP (Beta-192002) & 6380-6090 B.C. & Beauvechain (Transect b) & $\begin{array}{l}\text { Peaty stratum (c. } 0.10 \mathrm{~m} \text { thick) } \\
\text { in between tufa }\end{array}$ \\
\hline $320-330$ & $5300 \pm 40$ BP $(\mathrm{GrA}-28419)$ & 4260-3990 B.C. & Hamme-Mille (Transect $c_{1}$ ) & $\begin{array}{l}\text { Peaty stratum (c. } 0.60 \mathrm{~m} \text { thick), } \\
\text { above tufa layer. }\end{array}$ \\
\hline 285 & $3670 \pm 40$ BP $(\mathrm{GrA}-28456)$ & 2200-2170/2150-1930 B.C. & Hamme-Mille (Transect $\mathrm{c}_{2}$ ) & Wood fragment \\
\hline $550-560$ & $5260 \pm 40(\mathrm{GrA}-28458)$ & 4230-4190/4180-3970 B.C. & Hamme-Mille (Transect $\mathrm{c}_{2}$ ) & $\begin{array}{l}\text { Peat and tufa layers } \\
(>0.40 \mathrm{~m} \text { thick })\end{array}$ \\
\hline $230-240$ & $1300 \pm 40$ BP (Beta-192000) & 640-810 A.D. & Hamme-Mille (Transect d) & Peaty stratum (c. $0.40 \mathrm{~m}$ thick) \\
\hline $160-170$ & $920 \pm 40$ BP (Beta-191999) & 1020-1210 A.D. & Nethen (Transect $\left.h_{1}\right)$ & Thick peat ( $>3 \mathrm{~m}$ thick) \\
\hline $158-163$ & $575 \pm 25$ BP (KIA-28287) & 1300-1370/1380-1420 A.D. & Nodebais (Transect 1) & Loam, rich in organic matter \\
\hline $205-210$ & $585 \pm 25$ BP (KIA-28286) & 1300-1370/1380-1420 A.D. & Nodebais (Transect 1) & Loam, rich in organic matter \\
\hline \multicolumn{5}{|c|}{${ }^{14} \mathrm{C}$-dates extracted from Mullenders and Gullentops, 1966} \\
\hline $410-425$ & $4260 \pm 150$ BP $(\mathrm{Lv}-277)$ & $3350-2450$ B.C. & Nethen (Transect $\left.h_{2}\right)$ & Peat (c. $1.20 \mathrm{~m}$ thick) \\
\hline $510-520$ & $6350 \pm 150$ BP $(\mathrm{Lv}-279)$ & 5650-4950 B.C. & Nethen $\left(\right.$ Transect $\left.h_{2}\right)$ & Peat (c. $0.60 \mathrm{~m}$ thick) \\
\hline
\end{tabular}

${ }^{a}$ Calibrated at the $2 \sigma$ confidence level, using OxCal v3.10 (Bronk Ramsey, 1995; Bronk Ramsey, 2001). Calibration curve based on atmospheric data from (Reimer et al., 2004).

Between c. 2 and c. $3.5 \mathrm{~m}$ depth, a second unit can be defined. Unit 2 has a high content of organic material (soil and peat remnants) but is almost free of tufa. Radiocarbon dating places the formation of these sediments in the time span between 2900 B.C. and the Middle Ages (1000 A.D.).

The youngest unit (phase 3) generally consists of clastic sediments that were deposited during the last 1000 year. These homogeneous sediments show few traces of old soil surfaces or peat accumulation, which indicates a fast accumulation of sediments.

Delineation of the three sediment units is tentative, and radiocarbon ages so far do not allow studying the chronology of the valley infill in detail. Yet, morphological characteristics of the units differ enough to establish a reasonable temporal framework, which enables us to calculate average sedimentation and accumulation rates. These sedimentation rates probably varied over space and time. This explains why the deepest sample from the alluvial sediments (LV-279) is not the oldest one. However, average rates for each phase were similar over the whole alluvial plain and illustrate the dramatic shift in floodplain sedimentation (Table 2, Fig. 7): Over the last 1000 year, the accumulation rate has increased almost tenfold compared to earlier periods. This caused the end of peat formation and impeded the development of organic soils in most of the alluvium.

Obviously, there has been a dramatic increase in sediment supply towards the Nethen River from Medieval times onwards. Possible explanations are deforestation and intensification of agriculture, which took place in large parts of Europe during that period (e.g., Aerts et al., 1985). Similar effects of vast historical

Table 2

Holocene sediment volumes and masses stored in the Nethen alluvium

\begin{tabular}{|c|c|c|c|c|}
\hline Deposition phase & $\begin{array}{l}\text { Volume } \\
\left(\cdot 10^{6} \mathrm{~m}^{3}\right)\end{array}$ & $\begin{array}{l}\text { Accumulation } \\
\text { rate }\left(\mathrm{mm} \mathrm{a}^{-1}\right)\end{array}$ & $\begin{array}{l}\text { Mass of mineral } \\
\text { sediments }\left(\cdot 10^{6} \mathrm{t}\right)\end{array}$ & $\begin{array}{l}\text { Sedimentation } \\
\text { rate }\left(t \mathrm{ha}^{-1} \mathrm{a}^{-1}\right)\end{array}$ \\
\hline $\begin{array}{l}\text { Phase } 1 \\
\quad 9600-2900 \text { B.C. }\end{array}$ & $3.05 \pm 1.74$ & $0.2 \pm 0.1$ & $3.30 \pm 1.96$ & $1.8 \pm 1.1$ \\
\hline $\begin{array}{l}\text { Phase } 2 \\
2900 \text { B.C. }-1000 \text { A.D. }\end{array}$ & $2.62 \pm 1.75$ & $0.3 \pm 0.2$ & $3.28 \pm 2.23$ & $3.0 \pm 2.1$ \\
\hline $\begin{array}{l}\text { Phase } 3 \\
1000 \text { A.D.-present }\end{array}$ & $5.26 \pm 1.33$ & $2.5 \pm 1.2$ & $7.19 \pm 1.92$ & $26.1 \pm 12.8$ \\
\hline 9600 B.C.-present & $10.92 \pm 1.94$ & $0.4 \pm 0.1$ & $13.77 \pm 6.11$ & $4.1 \pm 1.9$ \\
\hline
\end{tabular}

Average accumulation and sedimentation rates in the alluvial plain of the Nethen. 
Table 3

Tentative (Holocene) sediment budget for the Nethen catchment

\begin{tabular}{lrc}
\hline Geomorphic unit & Erosion $\left(\cdot 10^{6} \mathrm{t}\right)$ & Deposition $\left(\cdot 10^{6} \mathrm{t}\right)$ \\
\hline Plateau, 0-3\% & $9.65 \pm 4.15$ & $7.05 \pm 3.03$ \\
Slope, 3-5\% & $9.20 \pm 2.12$ & $1.51 \pm 0.50$ \\
Slope, 5-8\% & $9.42 \pm 2.17$ & $0.28 \pm 0.09$ \\
Slope, $>8 \%$ & $15.61 \pm 3.59$ & $4.16 \pm 1.37$ \\
Thalweg (<8\%) & $3.98 \pm 0.91$ & $10.74 \pm 3.54$ \\
Total (plateau and dry valleys) & $47.85 \pm 9.08$ & $23.75 \pm 8.54$ \\
Alluvium & $?$ & $13.77 \pm 6.11$ \\
Total (Nethen catchment) & $47.85 \pm 9.08$ & $37.52 \pm 14.65$ \\
Sediment export: & & \\
$10.33 \pm 19.54 \cdot 10^{6} \mathrm{t}$ & & \\
Sediment delivery ratio: & & \\
$22 \pm 41 \%$ & & \\
\hline
\end{tabular}

deforestations were observed in the sediment archives of other European rivers (e.g., Larue et al., 1999; Larue, 2002; Macaire et al., 2002; Kukulak, 2003; Lespez, 2003). The extension of arable land and the cultivation of less favorable soils on steeper slopes and in the direct vicinity of permanent streams can improve coupling (sediment connectivity) between the plateau, slopes, and rivers, and facilitate sediment transfer through the fluvial system (e.g., Brunsden and Thornes, 1979; Brunsden, 2001; Harvey, 2001; Harvey, 2002). Holocene climate variability or extreme rainfall events may also have been an important driving factor (e.g., Bork and Bork, 1987; Kalis et al., 2003; Daniels and Knox, 2005). To evaluate the relative importance of human and climate related factors, however, sediment archives with a high resolution temporal framework are needed.

So far, geomorphic research in central Belgium has pointed the transition from the Subboreal to the Subatlantic Period (ca. 2700 BP) as the start of massive alluvial sedimentation in the river valleys (e.g., Tavernier, 1948; Mullenders et al., 1966; De Smedt, 1973). Peat strata and soil remnants within the Late Holocene sediments were given little attention. Our results show that in the alluvial plain of the Nethen large patches of peat continued to accumulate and stable phases of soil formation occurred after the Atlanticum, at least until the early Middle Ages. The majority of the silty and loamy sediments accumulated in the alluvial plain only later. In other words, the time span between the onset of the Subatlanticum and 1000 A.D. was of minor importance for the infill of river valleys.

\subsection{Sediment budget}

As shown in Table 3, considerable uncertainties are involved in the calculation of a long-term sediment budget. Nevertheless, an attempt is made to give an idea of the enormous amounts of sediment that have been transported through time. High errors on the values for sediment export and sediment delivery ratio are inevitable. We should also stress that no value is available for riverbank erosion. The Nethen is a meandering river and thus riverbank erosion does occur but this is limited to a narrow meander belt. Therefore, it does not affect the entire alluvial plain, but probably $<10 \%$ of it.

To evaluate the overall accuracy of the sediment budget, the calculated sediment export value is compared to the output of an empirical relationship between catchment area $(A$, ha) and specific sediment yield (SSY, $\mathrm{t} \mathrm{ha}{ }^{-1} \mathrm{a}^{-1}$ ), obtained for 26 cultivated catchments in the central Belgian loess belt over a period of 2 to 46years during the 20th century (Verstraeten and Poesen, 2001a). This formula states that $\mathrm{SSY}=26 A^{-0.35}$.

For the Nethen catchment, this results in an average contemporary annual sediment yield of $1.30 \mathrm{t} \mathrm{ha}^{-1}$ $\mathrm{a}^{-1}$. Using this figure, the mean annual sediment export for the Nethen catchment can be calculated to be $6800 \mathrm{t} \mathrm{a}^{-1}$. If we extrapolate this to the Holocene period $(\sim 11,600$ years $)$ the calculated sediment export becomes $79 \times 10^{6} \mathrm{t}$. Because the formula used here was derived for catchments under intensive present-day agriculture, it is certainly not applicable for the entire Holocene period. For the last 2500 year, which is the estimated period of agricultural land use in the region (Rommens et al., 2005), sediment export comes to $17 \cdot 10^{6} \mathrm{t}$, whereas for the period in which sediment unit 3 was deposited (1000 A.D.-present) a value of $6.8 \cdot 10^{6} \mathrm{t}$ is obtained. So, it is plausible that the real export value lies somewhere between $6.8 \cdot 10^{6}$ and $17 \cdot 10^{6} \mathrm{t}$, which corresponds well with the estimated export of c. $10.33 \times 10^{6} \mathrm{t}$ obtained in the sediment budget.

As expected, the majority of the sediments entering the Holocene sediment pathway originate from the steeper slopes. Some sediment is produced on the plateaus, but most of it is deposited in close proximity to its source. Overall, the sediment budget demonstrates that a substantial amount (50\%) of sediment is stored in the zero-order valleys and has not, until now, been transferred to higher order streams.

Moreover, dating of colluvial sediments suggests that soil erosion and sediment deposition in the zeroorder valleys at the fringes of the plateau started in the Early Iron Age (c. 800-400 B.C.) (Rommens et al., 2005) and was already considerable in the Roman Age (c. 0-400 A.D.) (Rommens, unpublished data). 
This is much earlier than the massive sediment deposition phase (unit 3) in the alluvial plain, which apparently only started at least 500 years later (during the Middle Ages, 500-1500 A.D.). So, deforestation of part of the catchment clearly started well before medieval times. Probably, this has triggered severe soil erosion all over the plateau and in many dry valleys, but because of insufficient coupling between slopes and permanent streams, for instance, it did not immediately induce a rise of sedimentation rates along the Nethen River. Sediment transport at a catchment scale is thus very likely to follow a nonlinear pathway (e.g., Brierly and Fryirs, 1999; Lang and Hönscheidt, 1999; Malmon et al., 2003; Lang et al., 2003), influenced by complex long-term interactions of sediment sources and sinks, which change through time. Sinks can switch into sources and vice versa, depending on human and climatic impact on the environment.

\section{Conclusions}

In the alluvial deposits of the Nethen, three sediment units could be distinguished on the basis of sedimentological properties and dated using ${ }^{14} \mathrm{C}$. The youngest unit, which started to accumulate during the Middle Ages (c. 1000 A.D.), contains 50\% of the total Holocene sediment mass. Mean sedimentation rates for these youngest deposits are almost 10 times as high as accretion rates earlier in the Holocene.

The sediment budget for the Nethen river catchment demonstrates that most of the Holocene sediments are stored as colluvial deposits on footslopes and in dry zero-order valley bottoms. Only $\sim 29 \%$ of the eroded material was delivered to the valleys of permanent streams, where it was stored as alluvial deposits, and only $\sim 21 \%$ has been transferred through the catchment and delivered to the higher order stream.

A study of colluvial sediments in the upstream area of the Nethen shows that, in the time span between the onset of the Iron Age (c. 800-400 B.C.) and A.D. 1000, a large volume of sediment was produced and stored in dry valleys. During that period, very little deposition took place in the alluvium. So, there exists a time lag of about one millennium between the higher erosion and sedimentation rates in the upstream area and the increase in sediment supply to the river valley. Early deforestations on the plateau, for instance, are therefore not necessarily represented in the contemporary sediment record of the alluvial plain downstream. This raises questions concerning the reliability of studies that aim to reconstruct environmental change in river or lake catchments by analysing the sediment archive at one location only. Further research to unravel the longterm routing mechanism of sediments through nonlinear sediment pathways could clarify this further.

\section{Acknowledgements}

The Ph.D. students and the technical staff of the Physical and Regional Geography Research Group are thanked for their contribution to the fieldwork. This project is funded by the K.U.Leuven, grant no. 3E020001. The GPS equipment was granted by the Fund for Scientific Research Flanders (Belgium), grant 1.5.114.04.

\section{References}

Aerts, E., Dupon, W., Van der Wee, H., 1985. De economische ontwikkeling van Europa: documenten-Deel I-Middeleeuwen. Leuven University Press, Leuven.

Baeyens, L., 1958. Bodemkaart van België. Kaartblad 104W Meldert. IWONL.

Baeyens, L., Dudal, R., 1959. Bodemkaart van België. Kaartblad 103W Duisburg. IWONL.

Baeyens, L., Tavernier, R., Scheys, G., 1957. Bodemkaart van België. Kaartblad 103E Hamme-Mille. IWONL.

Bertran, P., 2004. Soil erosion in small catchments of the Quercy region (southwestern France) during the Holocene. The Holocene 14 (4), 597-606.

Bork, H.-R., Bork, H., 1987. Extreme jungholozäne hygrische Klimaschwankungen in Mitteleuropa und ihre Folgen. Eiszeitalter und Gegenwart 37, 109-118.

Brady, N.C., 1990. The Nature and Properties of Soils. McMillan, New York.

Brierly, G.J., Fryirs, K., 1999. Tributary-trunk stream relations in a cutand-fill landscape: a case study from Wolumla Catchment, New South Wales, Australia. Geomorphology 28, 61-73.

Bronk Ramsey, C., 1995. Radiocarbon calibration and analysis of stratigraphy: the OxCal program. Radiocarbon 37 (2), 425-430.

Bronk Ramsey, C., 2001. Development of the radiocarbon program OxCal. Radiocarbon 43 (2A), 355-363.

Brunsden, D., 2001. A critical assessment of the sensitivity concept in geomorphology. Catena 42, 99-123.

Brunsden, D., Thornes, J.B., 1979. Landscape sensitivity and change. Transactions of the Institute of British Geographers, New Series 4, $463-484$.

Daniels, J.M., Knox, J.C., 2005. Alluvial stratigraphic evidence for channel incision during the Mediaeval Warm Period on the central Great Plains, USA. The Holocene 15 (5), 736-747.

De Roo, A.P.J., Wesseling, C.G., Jetten, V.G., Offermans, R.J.E., Ritsema, C.J., 1995. LISEM, Limburg Soil Erosion Model, User Manual. Department of Physical Geography, Utrecht University, The Netherlands.

De Smedt, P., 1973. Paleogeografie en kwartair-geologie van het confluentiegebied Dijle-Demer. Acta Geographica Lovaniensia 11, 130. 
FAO, 1998. World Reference Base for Soil Resources. World Soil Resources Reports 84 Rome.

Flanagan, D.C., Nearing, M.A., 1995. USDA-Water Erosion Prediction Project: Hillslope Profile and Watershed Model Documentation. NSERL Report No. 10, West Lafayette, IN.

Foster, I.D.L., Mighall, T.M., Wotton, C., Owens, P.N., Walling, D.E., 2000. Evidence for Medieval soil erosion in the South Hams region of Devon, UK. The Holocene 10 (2), 261-271.

Fryirs, K., Brierly, G.J., 2001. Variability in sediment delivery and storage along river courses in Bega catchment, NSW, Australia: implications for geomorphic river recovery. Geomorphology 38, 237-265.

Geurts, M.-A., 1976. Genèse et stratigraphie des travertins de fond de vallée en Belgique. Acta Geographica Lovaniensia $16,66$.

Goossens, D., 1987. Sedimentatiemechanismen bij natuurlijke stofdeeltjes in lucht. Ph.D. dissertation, K.U. Leuven, Belgium.

Grossman, M.J., 2001. Large floods and climatic change during the Holocene on the Ara River, Central Japan. Geomorphology 39, 21-37.

Gullentops, F., 1954. Contribution à la chronologie du Pleistocène et des formes du relief en Belgique. Mémoires de 1' Institut géologique de l' Université de Louvain 18 (4), $125-252$

Harvey, A.M., 2001. Coupling between hillslope and channels in upland fluvial systems: implications for landscape sensitivity, illustrated from the Howgill Fells, northwest England. Catena 42, $225-250$.

Harvey, A.M., 2002. Effective timescales of coupling within fluvial systems. Geomorphology 44, 175-201.

Kalis, A.J., Merkt, J., Wunderlich, J., 2003. Environmental changes during the Holocene climatic optimum in central Europe-human impact and natural causes. Quaternary Science Reviews 22, $33-79$.

Kukulak, J., 2003. Impact of Mediaeval agriculture on the alluvium in the San River headwaters (Polish Eastern Carpathians). Catena 51, 255-266.

Lang, A., 2003. Phases of soil erosion-derived colluviation in the loess hills of south Germany. Catena 51, 209-221.

Lang, A., Hönscheidt, S., 1999. Age and source of colluvial sediments at Vaihingen-Enz, Germany. Catena 38, 89-107.

Lang, A., Nolte, S., 1999. The chronology of Holocene alluvial sediments from the Wetterau, Germany, provided by optical and ${ }^{14} \mathrm{C}$ dating. The Holocene 9 (2), 207-214.

Lang, A., Bork, H.-R., Mäkel, R., Preston, N., Wunderlich, J., Dikau, R., 2003. Changes in sediment flux and storage within a fluvial system: some examples from the Rhine catchment. Hydrological Processes 17, 3321-3334.

Larue, J.P., 2002. Small valley bottom deposits in the sandy districts of the Sarthe basin (France): Climate and/or human origin? Geomorphology 45, 309-323.

Larue, J.P., Mahoué, J.-P., Monnier, J., 1999. Erosion in cultivated soils and river morphodynamics: The example of the Tortue Basin (Sarthe, France). Geodinamica Acta 12 (2), 57-70.

Lespez, L., 2003. Geomorphic responses to long-term land use changes in eastern Macedonia (Greece). Catena 51, 181-208.

Locher, W.P., de Bakker, H., 1994. Bodemkunde van Nederland. Deel 1: Algemene bodemkunde. Malmberg, Den Bosch.

Macaire, J.-J., Bellemlih, S., Cocirta, C., De Luca, P., Di-Giovanni, C., Gay-Ovejero, I., 2001. Quantification des flux et des stocks solides holocènes dans le bassin de la Loire (France). La Houille Blanche $8,35-38$.
Macaire, J.-J., Bellemlih, S., Di-Giovanni, C., De Luca, P., Visset, L., Bernard, J., 2002. Sediment yield and storage variations in the Négron River catchment (south western Parisian basin, France) during the Holocene period. Earth Surface Processes and Landforms 27, 991-1009.

Macklin, M.G., Passmore, D.G., Stevenson, A.C., Cowley, D.C., Edwards, D.N., O’Brian, C.F., 1991. Holocene alluviation and land-use change on Callaly Moor, Northumberland, England. Journal of Quaternary Science 6 (3), 225-232.

Malmon, D.V., Dunne, T., Reneau, S.L., 2003. Stochastic theory of particle trajectories through alluvial valley floors. Journal of Geology 111, 525-542.

Meade, R.H., 1982. Sources, sinks, and storage of river sediments in the Atlantic drainage of the United States. Journal of Geology 90, 235-252.

Morgan, R.P.C., Quinton, J.N., Smith, R.E., Govers, G., Poesen, J., Auerswald, K., Chisci, G., Torri, D., Styczen, M.E., 1998. The European soil erosion model (EUROSEM): a dynamic approach for predicting sediment transport from fields and small catchments. Earth Surface Processes and Landforms 23, 527-544.

Mullenders, W., Gullentops, F., 1957. Palynologisch onderzoek in de alluviale vlakte van de Dijle, te Heverlee-Leuven. Agricultura 5 (1), 57-64.

Mullenders, W., Gullentops, F., Lorent, J., Coremans, M., Gilot, E., 1966. Le remblaiement de la vallée de la Nethen. Acta Geographica Lovaniensia 5, 169-181.

Page, M.J., Trustrum, N.A., Dymond, J.R., 1994. Sediment budget to assess the geomorphic effect of a cyclonic storm, New Zealand. Geomorphology 9, 169-188.

Parrat, L.G., 1961. Probability and Experimental Errors. Wiley, New York.

Reid, L.M., Dunne, T., 2003. Sediment budgets as an organizing framework in fluvial geomorphology. In: Mathias Kondolf, G., Piégay, H. (Eds.), Tools in Fluvial Geomorphology. Wiley, New York, pp. 463-500.

Reimer, P.J., Baillie, M.G.L., Bard, and 26 others, 2004. IntCal04 terrestrial radiocarbon age calibration, 0-26Cal Kyr BP. Radiocarbon 46 (3), 1029-1058

Rommens, T., Verstraeten, G., Poesen, J., Govers, G., Van Rompaey, A., Peeters, I., 2005. Soil erosion and sediment deposition in the Belgian loess belt during the Holocene: establishing a sediment budget for a small agricultural catchment. The Holocene 15 (7), 1032-1043.

Soil Survey Staff, 2003. Keys to Soil Taxonomy. USDA-NRCS, Washington DC.

Tavernier, R., 1948. Les formations quaternaires de la Belgique en rapport avec l'évolution morphologique du pays. Bulletin de la Société Belge de Géologie 62, 609-641.

Taylor, M.P., Macklin, M.G., Hudson-Edwards, K., 2000. River sedimentation and fluvial response to Holocene environmental change in the Yorkshire Ouse Basin, northern England. The Holocene 10 (2), 201-212.

Trimble, S.W., 1999. Decreased rates of alluvial sediment storage in the Coon Creek Basin, Wisconsin, 1975-93. Science 285, $1244-1246$

Van Oost, K., Govers, G., Desmet, P., 2000. Evaluating the effects of changes in landscape structure on soil erosion by water and tillage. Landscape Ecology 15, 577-589.

Van Vliet, B., Langohr, R., 1981. Correlation between fragipans and permafrost with special reference to silty Weichselian deposits in Belgium and northern France. Catena 8, 137-154 
Verstraeten, G., Poesen, J., 2001a. Variability of dry sediment bulk density between and within retention ponds and its impact on the calculation of sediment yields. Earth Surface Processes and Landforms 26, 375-394.

Verstraeten, G., Poesen, J., 2001b. Factors controlling sediment yield from small intensively cultivated catchments in a temperate humid climate. Geomorphology 40, 123-144.
Walling, D.E., Russel, M.A., Hodgkinson, R.A., Zhang, Y., 2002. Establishing sediment budgets for two small lowland agricultural catchments in the UK. Catena 47, 323-353.

Zolitschka, B., 1998. A 14,000year sediment yield record from western Germany based on annually laminated lake sediments. Geomorphology 22, 1-17. 